\title{
Qualidade de Vida e Utilidade do Câncer de Mama em um Centro de Referência do SUS
}

Eixo temático: Execução de métodos de ATS.

Palavras-chave: neoplasias da mama; medidas de desfechos reportados pelo paciente; qualidade de vida relacionada à saúde.

Introdução. As medidas de desfechos reportados pelos pacientes são ferramentas importantes para captar as perspectivas dos pacientes sobre os resultados de saúde. O objetivo deste estudo foi avaliar a qualidade de vida relacionada à saúde e derivar o escore de utilidade de pacientes com câncer de mama, antes e após início da terapia de rotina, em um centro de referência para câncer no Brasil.

Métodos. Estudo de coorte prospectivo em que pacientes ambulatoriais recémdiagnosticadas com câncer de mama foram submetidas a uma entrevista em dois momentos: antes (baseline) e após início da terapia de rotina (6 meses de seguimento), com preenchimento dos questionários EQ-5D-3L/VAS e EORTC-QLQC30/BR23. Informações demográficas e clínicas adicionais foram revisadas em prontuários médicos.

Resultados. Para as 196 pacientes incluídas, os domínios do EQ-5D mais afetados foram dor/desconforto e ansiedade/depressão. Houve melhora parcial destes domínios, enquanto mobilidade/atividades usuais/autocuidado pioraram no seguimento pós-início da terapia. As escalas do EORTC-QLQ-C30/BR23 mais afetadas foram funcionalidade emocional, insônia, dor, prazer sexual e perspectiva sobre a própria saúde no baseline, enquanto dificuldades financeiras, fadiga e efeitos colaterais da terapia no seguimento. As médias sequenciais da VAS foram 71,4 (IC95\% 68,5-74,4) e 76,1 (95\% Cl73.3-78.8), enquanto as utilidades médias estimadas foram $71,2 \%(95 \% \mathrm{Cl} 68,6-73,7 \%)$ e $73,2 \%(95 \% \mathrm{Cl} 70,7-75,7 \%)$. No seguimento, a utilidade foi $68,9 \%$ (IC95\% 64,8-73\%) nos estágios III-IV e 69,2\% (IC95\% 65,2-73,1\%) naqueles em uso de $\geq 2$ esquemas quimioterápicos.

Conclusão. Em um contexto de comprometimento da funcionalidade emocional, carga de sintomas e dificuldades financeiras, o câncer de mama produziu utilidade de $70 \%$. Houve pequena melhora após cuidados de rotina, exceto nos casos de doença avançada e múltiplas quimioterapias. O menor ganho de utilidade do que VAS levanta a hipótese de que a transição para um estado com funcionalidade física mais comprometida pode ser pior avaliada pela comunidade do que pelos próprios pacientes. 


\section{ABSTRACT \\ Breast Cancer Quality of Life and Health-state Utility at a Brazilian Reference Public Cancer Center}

Introduction. Patient reported outcomes measure are important tools for capturing patients' perspectives on health outcomes. This study's aim was to evaluate health-related-quality-of-life and derive health-state-utility (HSU) from breast cancer patients, before and after routine therapy at a Brazilian reference public cancer center.

Methods. In a prospective cohort study, a consecutive sample of outpatients newly diagnosed with breast cancer was submitted to two interviews (baseline, 6-month) to complete EQ-5D-3L/VAS and EORTC-QLQ-C30/BR23 questionnaires. Demographic and clinical information was reviewed from medical records.

Results: For 196 patients, EQ-5D domains of pain/discomfort and anxiety/depression were mainly affected, but partially improved overtime, while mobility/usual activities/self-care worsened after therapy. EORTC-QLQ-C30/BR23 scales mostly affected were emotional functioning, insomnia, pain, sexual enjoyment and future self-health perspective at baseline, while financial difficulties, fatigue and therapy side-effects at follow-up. Overtime mean scores were 71.4 $(95 \% \mathrm{Cl} 68.5-74.4)$ and 76.1 (95\% CI73.3-78.8) for EQ-5D-VAS, and 0.712 $(95 \% \mathrm{Cl} 0.686-0.737)$ and $0.732(95 \% \mathrm{Cl} 0.707-0.757)$ for HSU. HSU was 0.689 $(95 \% \mathrm{Cl} 0.648-0.730)$ in stages III-IV, and $0.692(95 \% \mathrm{Cl} 0.652-0.731)$ under two/three chemotherapy regimens.

Conclusion. In a context of emotional functioning impairment, symptoms burden, and financial difficulties, breast cancer produced $70 \%$ of utility. There was little improvement after routine care, except in cases of advanced disease and multiple chemotherapies. The lower gain in HSU than VAS raises the hypothesis that a transition to a more compromised activity functioning state may be considered worse by the community than by the patients themselves. 